\title{
Integration and Synchronization of Population Policies Through Grand Design Population Development in Indonesia
}

\author{
Lutfi Agus Salim \\ Associate Profesor in Department Biostatistic and Demography, Faculty of Public Health, \\ Universitas Airlangga, Surabaya, Indonesia
}

\begin{abstract}
The problem of population in Indonesia is complex. Population policy in the era of decentralization is still not integrated and sustainable. Grand Design of Population Development is a guideline for population-oriented policies, strategies and development programs, which contains important current population issues, desired population conditions, population development programs, population development roadmaps covering population quantity control, quality development population, family development, spatial planning and population regulation and population administration development. Approach Grand Design of Population Development can influencing policy and responsive policy towards population dynamics. With the Grand Design of Population Development, a region can prepare itself to welcome the demographic bonus that can be done through improving human quality. Human development as an effort to develop capability the ability of human self, which contains four elements, namely productivity, equity, sustainability and empowerment. The roadmap set out in Grand Design of Population Development will be implemented on an ongoing basis to improve human quality, reflected in the increasing Human Development Index.
\end{abstract}

Keywords: Population policies, grand design population development.

\section{Introduction}

People is the object and subject of development (people centered development). To reach a development goal is determined by the human development, economy, culture and national character. Development oriented to the potential and needs of social, economic, cultural, physical and spiritual tranquility of the people. A large population will become a force for national development if it is accompanied by a qualified and competitive population, because a high-quality population will accelerate the achievement of economic and social growth $^{(1)}$.

\section{Corresponding Author:}

\section{Lutfi Agus Salim}

Associate Profesor in Department Biostatistic and Demography, Faculty of Public Health, Universitas Airlangga, Surabaya, Indonesia e-mail: lutfi.as@fkm.unair.ac.id
Some of the regulations that form the basis of the drafting of a Grand Design for Population Development (GDPD) are as follows: 1.) Indonesian`s Law Constitution of 1945 (Preamble, Article 28B, article 33 and article 34); 2.) Law Number 24 of 2013 concerning Population Administration; 3.) Law No. 39 of 1999 concerning Human Rights; 4.) Government Regulation Number 87 of 2014 concerning Development of Population and Family Development, Family Planning and Family Information Systems; 5.) Presidential Regulation 153 of 2014 concerning GDPD ${ }^{(2)}$.

The population in an area in a particular year is influenced by birth, death and migration (3). Births that occur will be incremental while deaths will be a deduction from the population. Likewise with migration, the number of people come is supplementary and the people left is reduced ${ }^{(4)}$.

In line with regional autonomy, a population development effort that is consistent and sustainable is the most appropriate choice amid complex population 
dynamics $^{(5)}$. Based on these problems, the researcher raised the research topic with the title "Grand Design of Population Development in improving the quality of human development in Indonesia"

Problem Formulation: The total population in the world reached seven billion and is expected to nine billion by 2035. More than three-quarters of the world's population live in developing countries, one of which is Indonesia with a population of more than 237 million people in the year 2010 with a population growth rate of $1.3 \%$ per year ${ }^{(3)}$.

Projection shows that population of Indonesia will keep increasing in the next twenty five years from, 238,5 million in 2010 to 305,6 million in 2035. However, In the period of 2010-2015 and 2030-2035 the population growth rate will decrease from 1,38 percent to 0,62 percent per year. This decrease is determined by a decrease of the birth and death rates. The decrease rate caused by birth is faster than that caused by death. The Crude Birth Rate (CBR) will decrease from approximately 21,0 for 1000 population in the beginning of the projection to 14,0 per 1000 population in the end of the projection period. Meanwhile the Crude Dead Rate (CDR) will increase from 6,4 per 1000 population to 8,8 per 1000 population in the same period of time ${ }^{(6)}$.

In the same period of time, the productive ages, 15 64 years, increase from 66.5 percent to 67.9 percent and those of 65 years and above increase from 5.0 percent to 10.6 percent. This change in age composition decreased the dependency ratio from 50.5 percent in 2010 to 47.3 percent in 2035. Then the decrease in the dependency ratio means a decrease of economic burden to the population in productive ages which has always been supporting the unproductive age population ${ }^{(6)}$.

Indonesia Gold in 2045 is a condition in Indonesia is superior, advanced to compete with other nations in the world in $2045^{(7)}$. In that year Indonesia also must be moved out of the zone Middle Income Trap which can be achived if carried out policy reforms focused on increasing the significant economic growth and strengthening of human resource capacity ${ }^{(1)}$.

\section{Literatures:}

People Centered Development: Malthus says "If there are no restrictions on population will multiply very quickly and fulfill some parts of the earth's quickly. Humans need food for life but rate of growth of food is much slower"(8). Population projection is a scientific calculation based on assumptions of the components of the population growth rate, namely birth, death and movement ${ }^{(12)}$.

Development as a effort or a series for growth and change that are planned and carried out consciously by a nation, state and government, towards modernity in the context of nation building ${ }^{(13)}$. Development is a process of change all social systems, such as politics, economy, infrastructure, defense, education and technology, institutions and culture ${ }^{(14)}$. Development as an economic, social and cultural transformation ${ }^{(15)}$.

Development in this article is defined as a form of change that is planned; each person or group of people certainly hope have a better shape or even perfect than the previous situation; to realize this hope certainly require a plan. Development planning is felt more as a more rational and orderly effort for the development of undeveloped or newly developing societies ${ }^{(16)}$.

According to Heran is a useful change towards sustainable social and economic systems which are decided as the will of a nation (17). Development is a process that moves in a straight line, namely from backward society to developed country society. Development was first used in the sense of economic growth. A community is considered successful in carrying out development, if the economic growth of the community is quite high ${ }^{(18)}$.

Problem Solusion: Development is a process of transformation of the community from a situation to another situation that is closer to the ideals of the community, though two things to consider, continuity and change. Development is a process of change that occurs naturally as a result of development ${ }^{(14)}$. Thus, the development process occurs in all aspects of community life, economic, social, cultural, political, which takes place at the macro (national) and micro (community/ group) level ${ }^{(3)}$.

This paradigm gives the role of the individual as a subject, the actor who sets goals, controls resources and directs the processes that affect his life. According to this paradigm, the main goal of development is to create an environment that allows its people to enjoy a creative, healthy and long-life. All development policies must be carried out based on the principle of people centered development in order to achieve population-oriented development. 
Quality of the population is the condition of the population in physical and non-physical aspects which include the degree of health, education, employment, productivity, social level, resilience, independence, intelligence, as a basic measure to develop abilities and enjoy life as human beings who are pious, cultured, have personality, nationally and live well.

\section{Funding:}

Grand Design of Population Development (GDPD): Regional development is carried out through the development of regional autonomy and the regulation of resources that provide opportunities for the realization of good governance. Mandated by Law 23 of 2014, one of the affairs of population control is to guide and synchronize population control policies. One product of the integration and synchronization of population policy is the GDPD document which can be used as guidance on population-oriented policies, strategies and development programs. According to Presidential Regulation 153 of 2014 concerning the GDPD, it is stated that GDPD is a formulation of population development planning for the next 25 years and is elaborated every five years which contains important issues of current population, population conditions desirable, population development program, population development roadmap which includes population quantity control, population quality development, family development, spatial distribution and population regulation and population administration development.

Grand Design of Population Development can be used as a guide for stakeholders in local governments in integrating population policies, targets and programs into Regional Mid-Term Development Plan (RPJMD) document, both influencing policies and responsive policies on population dynamics in the regions. Especially, GDPD can accelerate development and can integrate the population development program.

\section{Discussion}

Policy And Strategy Fill In Demographic Deviden By GDPD: In 2020 and 2030 Indonesia will receive Demographic Deviden. the success in exploiting the demographic bonus is affected by the government's readiness to prepare a qualified workforce. Furthermore, the government has a very important role to manage the resource potential of Indonesia( ${ }^{(19)}$.

A country have a demographic deviden if the population of productive age (15-64 years) more than the not-productive age ( $0-14$ years and 65 years and above). The comparison between the two population groups is called the Dependency Ratio. The economic benefit due to the decrease in the Dependency Ratio is called the Demographic Deviden. The decline in the dependency ratio at some point will reach its lowest point and turn back up again, when it shows the lowest number which is usually under $50 \%$, called The Window of Opportunity where the opportunity is very short only occurs once in a decade of the entire life journey population ${ }^{(20)}$.

A country or region is said to have a demographic bonus if the dependency ratio is below 50.0 percent. A demographic deviden is an opportunity for a country's economic prosperity because of the large proportion of the productive population. If this opportunity is not utilized to its full potential, it will be an anti demographic (bomb disaster) bonus.

With the GDPD, an area can prepare itself to welcome demographic deviden that can be done through improving the quality of public health, especially the health of the productive age population so that during the elderly boom, the aging population will not be a problem (especially the problem of funds swelling health insurance), improving the quality of education and developing skills, controlling population growth rates and supporting economic policies.

Strategies that can be taken by the government in picking demographic deviden include:

Improving the quality of adolescent: The development of a prosperous family will provide educational platforms for future generations, especially adolescents who will soon enter the productive age. Encourage the creation of quality families so that it is expected to produce a quality generation, especially for adolescents in the family, restore family functions so that they can help the development process of adolescents who are full of dynamics, provide a forum or event that provides opportunities for adolescents to appreciate their talents and abilities, incorporate life learning skills into the school curriculum so that graduates can be ready to use, maximizing the GenRe Program in schools, colleges and the surrounding environment through advocacy and IEC, increasing awareness and participation of governments and stakeholders in making pro-youth policies.

Improving the quality of education: Decreasing 
the number of children born gives flexibility to improve family quality. All expenditures can be more focused on education and health to improve the quality of competitive human resources. Improving the quality of the population of productive age can be done by providing skills that are in accordance with the needs of the labor market with competitive quality. Preparation and utilization of demographic deviden one of which includes the expansion of universal secondary education and strengthening the linkages of vocational and industrial education and training.

Placing elderly people as a asset, not a burden: Being in the era of demographic deviden and their continuation in the future, the increase in the elderly population in the future can be used as a potential rather than a burden. Older people with health problems and declining productivity can be a burden. But with the improvement of the quality of existing health, the elderly population is expected to continue to be able to produce. To get a productive elderly population, population-based development programs are needed and the programs are long-term.

Improving a Health Program: Development programs in health sector that prepare a healthy population, not easily sick, so that those who later enter old age will still be healthy. With good health, they can still be productive in economic activities. While preparing healthy people, but the state must also protect them with health insurance. In addition, from the community's point of view, there must be a continuing awareness program to save money or participate in a pension fund program that can be relied upon when retirement has arrived.

The strategies are as follows: Increasing access and quality of primary level health services, Improving Access and Quality of Referral Health Services, Healthy Living Community Movement Program and Family Approach

Economic Empowerment: With the Demographic Bonus a Window of Opportunity through birth is prevented. This fact will increase significantly towards increasing family opportunities for productive activities. Productive activities will lead to an increase in community welfare, namely: 1) increasing women's motivation to enter the labor market, 2) increasing women's participation, 3) saving society and 4) human capital (human capital) available.

Importance of GDPD on Human Quality Development: Human development as an effort to develop the ability of human self, which contains four elements, namely productivity, equity, sustainability and empowerment. Quality human development that has been achieved by an area can be done by measuring the quality of development using Human Development Index (HDI) which include 3 parameters: 1) Success in health, by looking at life expectancy, 2) The ability to reflect on the success of educational development by looking at old expectations school and length of school, 3) The amount of goods and services that can be provided by the community to its citizens is by looking at the purchasing power parity of the community.

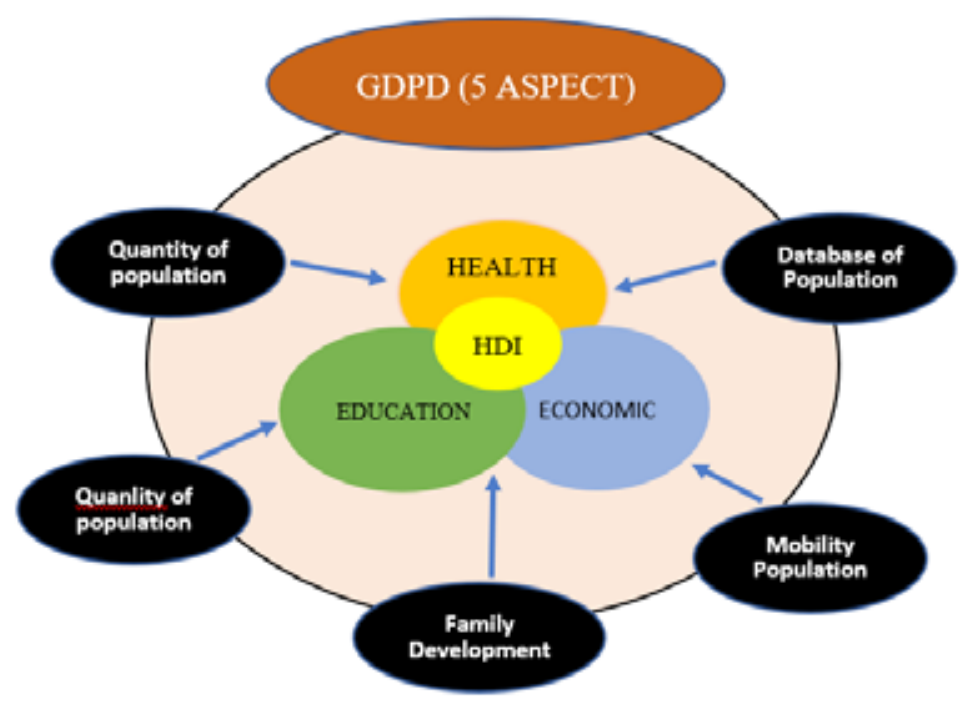

Figure 1. Contribution of GDPD in HDI 
Meanwhile GDPD is a formulation of population development planning which includes five aspects, namely population quantity control, population quality development, family development, spatial planning and population regulation and population administration development. The five aspects of GDPD are very closely related to efforts to develop human quality through its deciding components. If a regency/municipality has compiled GDPD properly according to the stipulated provisions, then in fact the efforts of the regency/city in the development of human quality are already on the correct roadmap. The direction of development policies and programs in GDPD has been made, medium term and long term. The flow of importance of GDPD in Human Quality Development can be described as follows:

\section{Conclusion}

Some recommendations from the grand design of population:

Utilization of GDPD in the roadmap for the development of human quality and sustainable development, because most of the population programs contained in GDPD are promoting human development and sustainability.

Integration, Synchronization and Synergy of GDPD programs and roadmaps relating to human quality development and sustainable development.

Strengthened networking of policies and programs among stakeholders in building population governance to support the creation of sustainable development.

It must be realized from the start that population development through quantity control efforts is a longterm investment and the results will be felt in the future.

Conflict of Interest: The authors have no conflict of interest with the material presented in this paper

\section{Sources of Funding: None}

Ethical Clearance: None. My paper is an idea and policy analysis to solve population problems

\section{References}

1. Bloom D, Canning D, Sevilla J. The demographic dividend: A new perspective on the economic consequences of population change. Rand Corporation; 2003.

2. Krippendorff K. Content analysis: An introduction to its methodology. Sage publications; 2018.

3. Central Bureau of Statistics. Indonesia Population Projection 2010-2035. 2013.

4. Haupt A, Kane TT. Population handbook, the 5th edition. Population Reference Bureau. 2004;

5. Haidy N A, S. Wongkaren T. Population policies and program in Indonesia. Occasional Papers. 2001;123(Populaiton and Health Series).

6. Bijak J, Courgeau D, Silverman E, Franck R. Quantifying paradigm change in demography. Demographic Research. 2014;30:911-24.

7. Bappenas, Central Bureau of Statistics, UNFPA. Indonesian Population Projection 2010-2045. Jakarta: Central Bureau of Statistics; 2013.

8. Burch TK. Demography in a new key: A theory of population theory. Demographic research. 2003;9:263-84.

9. Conway E. 50 Gagasan Ekonomi yang Perlu Anda Ketahui. Jakarta: Erlangga. 2015.

10. Skousen M. Sang Maestro Teori-teori ekonomi modern. Jakarta, Jakarta Prenada. 2005;

11. Ambrose AF, Paul G, Hausdorff JM. Risk factors for falls among older adults: a review of the literature. Maturitas. 2013;75(1):51-61.

12. Smith SK, Tayman J, Swanson DA. State and local population projections: Methodology and analysis. Springer Science \& Business Media; 2006.

13. Junaidi J, Hardiani H. Dasar--Dasar Teori Ekonomi Kependudukan. Hamada Prima; 2009.

14. Courgeau D. Probability and social science: Methodological relationships between the two approaches. Vol. 10. Springer Science \& Business Media; 2012.

15. Pires JO, Garcia F. Productivity of nations: a stochastic frontier approach to TFP decomposition. Economics Research International. 2012;2012.

16. Isserman AM. The accuracy of population projections for subcounty areas. Journal of the american Institute of Planners. 1977;43(3):247-59.

17. Héran F. Demography and its vocabulary over the centuries: A digital exploration. Population \& Societies. 2013;(10):1-4.

18. Hadizadeh Esfahani A. Exploring peoplecentred development in Melbourne Docklands redevelopment: Beyond physical development and collaborative planning. 2013; 
19. Wisnumurti AAGO, Darma IK, Suasih NNR. Government Policy of Indonesia to Managing Demographic Bonus and Creating Indonesia Gold in 2045. Journal Of Humanities And Social Science (IOSR-JHSS). 2018;23(1):23-34.
20. Courgeau D, Franck R, Key J. Demography, a fully formed science or a science in the making? An outline programme. Population. 2007;62(1):39-45. 